\title{
Hodnocení stavu útvarů povrchových vod v České republice za období 2013-2015
}

\section{PETR TUŠIL, PAVEL RICHTER, PETR VYSKOČ, RENATA FILIPPI, MARTIN DURČÁK}

\author{
Klíčová slova: hodnocení stavu povrchových vod - vodní útvar - reprezentativní profil - ekologický stav - \\ ekologický potenciál - biologické složky - chemický stav - prioritní látky
}

\section{SOUHRN}

Tento článek si klade za cíl seznámit odbornou veřejnost se souhrnnými výsledky hodnocení ekologického a chemického stavu, resp. potenciálu útvarů povrchových vod kategorie "řeka" a kategorie "jezero" za období let 2013-2015 v České republice, které byly v roce 2017 realizovány Výzkumným ústavem vodohospodářským T. G. Masaryka, v. v. i. (dále VúV TGM). Současně jsou zmíněny postupy a metody využité $k$ realizaci hodnocení stavu vod. V závěru článku jsou uvedena konkrétní doporučení, jejichž zajištění umožní v maximální možné míre optimalizovat následné hodnocení stavu povrchových vod, které proběhne v roce 2019, prričemž právě toto hodnocení stavu povrchových vod bude jedním ze zásadních podkladů pro aktualizaci všech úrovní plánů povodí. Všechna prezentovaná agregovaná data vznikla zpracováním primárních dat z monitoringu povrchových vod, která na základě smluvních vztahů poskytly v roce 2017 jednotlivé státní podniky Povodí. Data o vybraných prioritních a prioritních nebezpečných látkách v biotě využitá pro hodnocení chemického stavu útvarů povrchových vod byla poskytnuta z monitoringu pevných matric, který zajištujuje Český hydrometeorologický ústav (dále jen ČHMú). Vzhledem k rozsahu a povaze problematiky není cílem tohoto článku podrobnější analýza souvislostí, př́čin a faktorů ovlivñující výsledky předkládaného hodnocení stavu útvarů povrchových vod jako rovněž srovnání s výsledky hodnocení stavu útvarů povrchových vod v prvním a druhém plánovacím cyklu.

\section{ÚVOD}

Obecně hodnocení stavu útvarů povrchových vod v podmínkách České republiky představuje podle požadavků národních právních předpisů a Směrnice Evropského parlamentu a Rady 2000/60/ES ze dne 23. ŕíjna 2000, kterou se stanoví rámec pro činnost Společenství v oblasti vodní politiky [1] (dále jen Rámcová směrnice), hodnocení stavu vodních útvarů v kategoriích "řeka“ a "jezero". Současně je potřeba zmínit, že hodnocení stavu vodních útvarů je nedílnou součástí všech úrovní plánů povodí, které se zpracovávají v šestiletých cyklech v souladu s príslušnými ustanoveními zákona č. 254/2001 Sb., o vodách, ve znění pozdějších předpisů [2] (dále jen vodní zákon). Výsledky hodnocení jsou následně zásadním podkladem pro návrh programu opatření na zlepšení stavu vod a dalších aktivit v oblasti výkonu vodohospodářských činností na úrovni České republiky i dílčích povodí.

Podle § 4 vyhlášky č. 98/2011 Sb., o způsobu hodnocení stavu útvarů povrchových vod, způsobu hodnocení ekologického potenciálu silně ovlivněných a umělých útvarů povrchových vod a náležitostech programů zjištování a hodnocení stavu povrchových vod, ve znění pozdějších predpisů [3], má být stav útvarů povrchových vod vyhodnocen jednou za tři roky. V rámci procesu zpracování druhých plánů povodí bylo na národní úrovni dohodnuto, že obdobím pro hodnocení stavu vod v České republice pro tyto plány bylo období 2010-2012.

\section{METODICKÉ POSTUPY POUŽITÉ PRO ŘEŠENÍ}

Předkládané hodnocení stavu povrchových vod za období 2013-2015 bylo realizováno podle schválených metodických postupů pro 2. plánovací cyklus $\checkmark$ oblasti vod a vzhledem k cílům použitým při hodnocení stavu povrchových vod pro 2. plánovací cyklus.

Pro samotné řešení hodnocení stavu byly použity certifikované metodické postupy a certifikované metodiky schválené Odborem ochrany vod MŽP, které jsou dostupné na www.mzp.cz/cz/metodiky_hodnoceni_stavu_vod. Tyto postupy plně respektují požadavky Rámcové směrnice [1] a souvisejících dokumentů (ostatní směrnice Evropské unie např. [4-6] a př́slušné Guidance dokumenty), současně tyto postupy rovněž respektují požadavky národních právních předpisů a dalších relevantních dokumentů $[2,3,7]$. Součástí hodnocení stavu povrchových vod bylo i doplnění potřebných informací k reprezentativním profilům z hlediska potřeb jednotlivých metodických postupů hodnocení biologických složek ekologického stavu.

Podle ustanovení vodního zákona [2] se stavem povrchových vod (celkový stav) rozumí obecné vyjádření stavu útvaru povrchové vody určené ekologickým nebo chemickým stavem podle toho, který je horší. Při systému vyhodnocení stavu povrchových vod byl v souladu s požadavky relevantních legislativních předpisů na úrovni České republiky i Evropské unie vždy dodržen princip „one out - all out". Platí tedy, že pro výsledné hodnocení je vždy určující nejhorší z výsledků vyhodnocení relevantních dílčích složek, což je v konečném důsledku klíčové pro výslednou klasifikaci stavu konkrétního útvaru povrchových vod.

Systém hodnocení chemického a ekologického stavu/potenciálu povrchových vod v České republice se dělí do dvou samostatných celků - systém hodnocení ekologického stavu/potenciálu a systém hodnocení chemického stavu útvarů povrchových vod. Každá z těchto částí má své specifické přístupy a podmínky hodnocení a stejně tak i rozsah hodnocených parametrů a matric, požadavky na četnost sledování, kvalitu dat atd.

Vyhodnocení chemického i ekologického stavu/potenciálu bylo realizováno na základě reálně naměřených dat v reprezentativních profilech útvarů povrchových vod, kde probíhal v daném období situační nebo provozní monitoring. Každý útvar nebo skupina útvarů má v podmínkách České republiky určeno právě jeden reprezentativní profil, $v$ několika prípadech je jedním 
Tabulka 1. Kategorie útvarů povrchových vod

Table 1. Surface water bodies - categories

\begin{tabular}{lll}
$\begin{array}{l}\text { Kategorie útvarů } \\
\text { povrchových vod }\end{array}$ & $\begin{array}{l}\text { Počet útvarů } \\
\text { povrchových } \\
\text { vod }\end{array}$ & $\begin{array}{l}\text { Procento útvarů } \\
\text { povrchových } \\
\text { vod (\%) }\end{array}$ \\
\hline „řeka“ & $\mathbf{1 0 4 4}$ & $\mathbf{9 3 , 1}$ \\
\hline řeka - přirozený & 951 & 84,8 \\
\hline řeka - silně ovlivněný & 89 & 7,9 \\
\hline řeka - umělý & 4 & 0,4 \\
\hline "jezero“ & $\mathbf{7 7}$ & $\mathbf{6 , 9}$ \\
\hline $\begin{array}{l}\text { jezero - silně ovlivněný } \\
\text { jezero - umělý }\end{array}$ & 73 & 6,5 \\
\hline $\begin{array}{l}\text { Celkem - útvarů } \\
\text { povrchových vod }\end{array}$ & $\mathbf{1 1 2 1}$ & 0,4 \\
\hline
\end{tabular}

Tabulka 2. Celkový stav útvarů kategorie "řeka" a "jezero"

Table 2. Overall status of surface water bodies in categories "river" and "lake"

\begin{tabular}{lll} 
Celkový stav & $\begin{array}{l}\text { Počet útvarů } \\
\text { povrchových } \\
\text { vod }\end{array}$ & $\begin{array}{l}\text { Procento útvarů } \\
\text { povrchových } \\
\text { vod (\%) }\end{array}$ \\
\hline Kategorie „řeka“ & $\mathbf{1 0 4 4}$ & $\mathbf{1 0 0}$ \\
\hline dobrý & 94 & 9,0 \\
\hline nevyhovující & 946 & 90,6 \\
\hline neklasifikováno & 4 & 0,4 \\
\hline Kategorie „jezero“ & $\mathbf{7 7}$ & $\mathbf{1 0 0}$ \\
\hline dobrý & 5 & 6,5 \\
\hline nevyhovující & 63 & 81,8 \\
\hline neklasifikováno & 9 & 11,7
\end{tabular}

reprezentativním profilem hodnoceno dva nebo více útvarů povrchových vod kategorie "řeka”. Výsledné hodnocení chemického a ekologického stavu/ potenciálu bylo vztaženo na celý vodní útvar, v němž se reprezentativní profil nachází. Pokud $v$ reprezentativním profilu neproběhl v hodnoceném období odpovídající monitoring, nebyl príslušný stav vodního útvaru klasifikován.

Pro hodnocení jednotlivých biologických složek ekologického stavu/potenciálu útvarů povrchových vod - kategorie „řeka“ - byla vyhodnocena dostupná data z reprezentativních profilů s využitím funkčních možností nástroje informačního systému ARROW, který provozuje ČHMÚ (dále jen IS ARROW). Hodnocení chemických a fyzikálně-chemických parametrů v rámci klasifikace chemického stavu a ekologického stavu/potenciálu útvarů povrchových vod bylo realizováno prostřednictvím upravených softwarových nástrojů vyvinutých VÚV TGM [8]. Hodnocení všeobecných fyzikálně-chemických složek a biologických složek v rámci ekologického potenciálu útvarů povrchových vod kategorie "jezero" bylo realizováno Biologickým centrem Akademie věd České republiky, v. v. i. V rámci hodnocení ekologického stavu/potenciálu útvarů

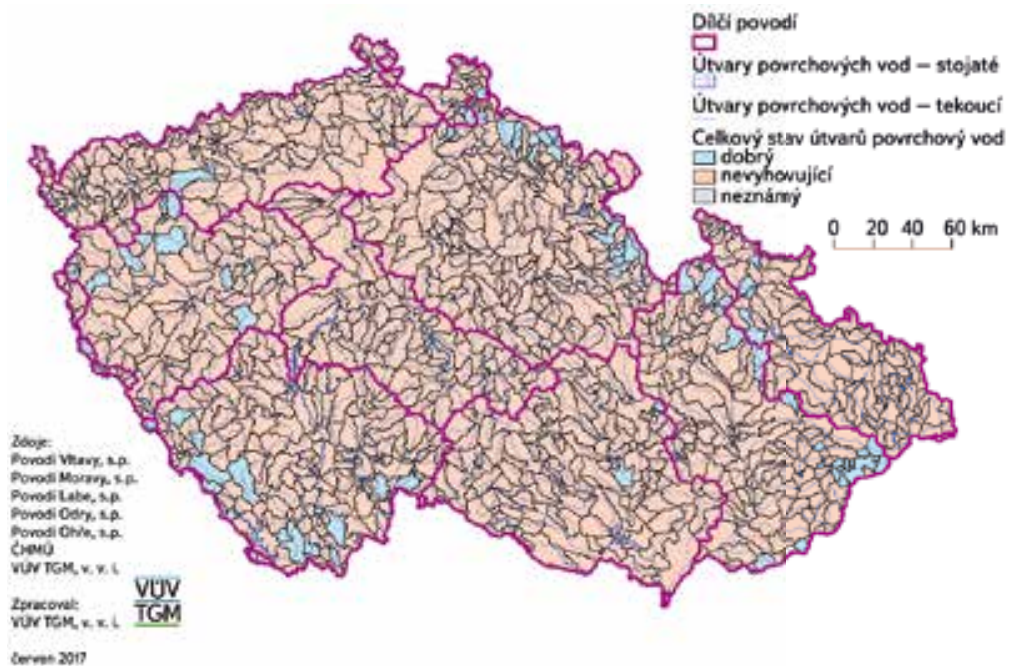

Obr. 1. Celkový stav útvarů povrchových vod za období 2013-2015 v České republice Fig. 1. Overall status of the surface water bodies for the 2013-2015 period in the Czech Republic

povrchových vod nebyly, stejně jako $v$ 2. plánovacím cyklu, hodnoceny hydromorfologické složky, a to především z důvodu absence monitorovaných dat a pro praktické potřeby hodnocení nedostatečné metodické podpory.

Pro realizaci hodnocení stavu povrchových vod byla poskytnuta data z Programu monitoringu povrchových vod státních podniků Povodí za období 2013-2015, včetně přiřazení reprezentativních profilů monitoringu k př́slušným vodním útvarům povrchových vod v jednotném formátu a struktuře vhodném pro hromadné zpracování dat

$\checkmark$ rámci hodnocení chemického stavu a ekologického stavu/potenciálu útvarů povrchových vod (kategorie „řeka“ i "jezero“), viz tabulka 1, byly použity oficiální platné metodické postupy [9-20].

\section{VÝSLEDKY}

Přehled výsledků hodnocení stavu útvarů povrchových vod je dále uveden v tabulkové a grafické formě v agregované podobě za území České republiky.

\section{Celkový stav útvarů povrchových vod}

Následující tabulka 2 uvádí prehled vyhodnocení celkového stavu útvarů kategorie "řeka“ a "jezero“ včetně procentuálního zastoupení v dané kategorii hodnocení.

Vyhodnocení celkového stavu útvarů povrchových vod v rámci České republiky je mapově znázorněno na obr. 1.

Z výše uvedených výsledků vyplývá, že více než 90 \% útvarů povrchových vod kategorie "řeka“ byla v hodnoceném období 2013-2015 v nevyhovujícím celkovém stavu. Podobně je tomu i u celkového stavu útvarů kategorie "jezero", kde je do nevyhovujícího stavu zařazeno více než 81 \% útvarů.

\section{Ekologický stav/potenciál útvarů povrchových vod}

$\checkmark$ následující tabulce 3 je uveden přehled agregovaných výsledků hodnocení ekologického stavu/potenciálu útvarů kategorie "řeka" a "jezero" v jednotlivých klasifikačních třídách. 


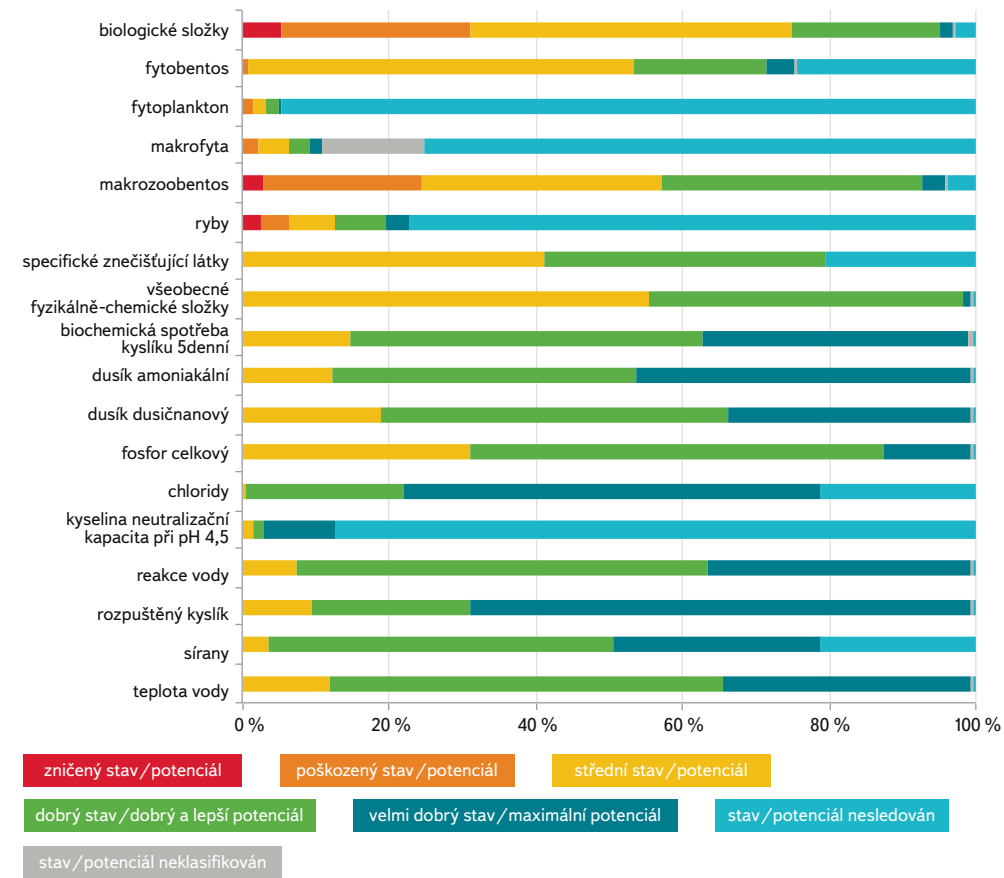

Obr. 2. Ekologický stav/potenciál útvarů povrchových vod kategorie „řeka“ podle hodnocení jednotlivých složek a jednotlivých všeobecných fyzikálně-chemických složek Fig. 2. Ecological status/potential of the surface water bodies in categories "river" and "lake" according to individual elements and individual physico-chemical elements

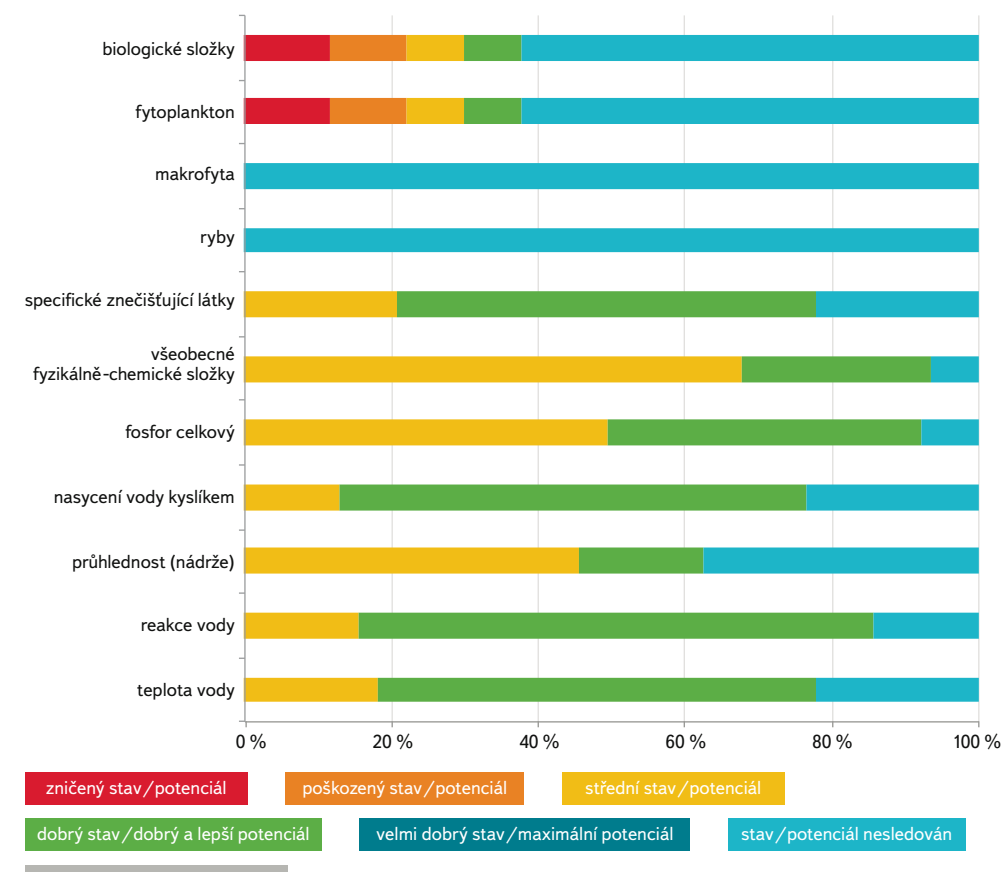
stav/potenciál neklasifikován

Obr. 3. Ekologický potenciál útvarů povrchových vod kategorie "jezero" podle hodnocení složek a jednotlivých všeobecných fyzikálně-chemických složek

Fig. 3. Ecological potential of the surface water bodies in category "lake" according to the assessment of the elements and individual physico-chemical elements
Tabulka 3. Ekologickýstav/potenciál útvarů povrchových vod kategorie „reka" a "jezero" Table 3. Ecological status/potential of the surface water bodies in categories "river" and "lake"

\begin{tabular}{lll} 
Ekologický stav/potenciál & $\begin{array}{l}\text { Počet útvarů } \\
\text { povrchových } \\
\text { vod }\end{array}$ & $\begin{array}{l}\text { Procento } \\
\text { útvarů } \\
\text { povrchových } \\
\text { vod (\%) }\end{array}$ \\
\hline Kategorie „řeka“ & $\mathbf{1 0 4 4}$ & $\mathbf{1 0 0}$ \\
\hline $\begin{array}{l}\text { velmi dobrý stav/maximální } \\
\text { potenciál }\end{array}$ & 1 & 0,1 \\
\hline dobrý stav/dobrý a lepší potenciál & 127 & 12,2 \\
\hline střední stav/potenciál & 589 & 56,4 \\
\hline poškozený stav/potenciál & 268 & 25,7 \\
\hline zničený stav/potenciál & 55 & 5,2 \\
\hline neklasifikované útvary & 4 & 0,4 \\
\hline Kategorie „jezero“ & $\mathbf{7 7}$ & $\mathbf{1 0 0}$ \\
\hline dobrý a lepší potenciál & 13 & 16,9 \\
\hline střední potenciál & 42 & 54,4 \\
\hline poškozený potenciál & 8 & 10,4 \\
\hline zničený potenciál & 9 & 11,7 \\
\hline neklasifikované útvary & 5 & 6,6
\end{tabular}

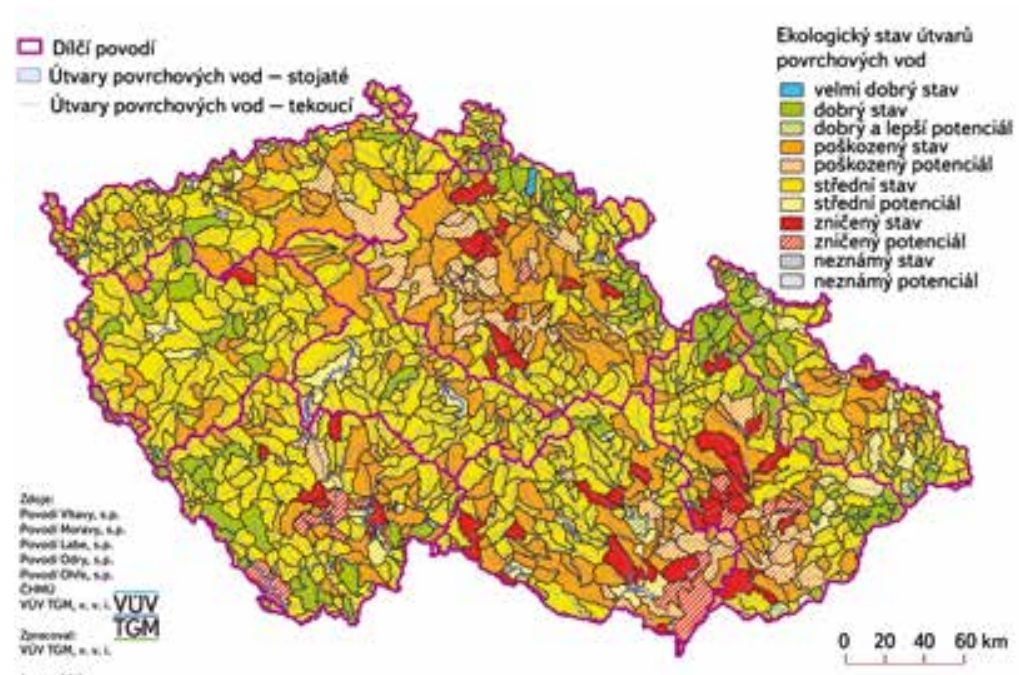
carmono

Obr. 4. Ekologický stav a ekologický potenciál útvarů povrchových vod za období 2013-2015 v České republice

Fig. 4. Ecological status/potential of the surface water bodies in the Czech Republic for the period 2013-2015 
Tabulka 4. Vybrané specifické znečištujici látky, které překračují NEK u více než 1 \% útvarů povrchových vod kategorie „řeka"

Table 4. Selected river basin specific pollutants exceeding EQS of more than $1 \%$ of the surface water bodies in category "river"

\begin{tabular}{|c|c|c|c|}
\hline Látka & $\begin{array}{l}\text { Procento útvarů povrchových } \\
\text { vod s překročením NEK (\%) }\end{array}$ & $\begin{array}{l}\text { Počet útvarů povrchových } \\
\text { vod s překročením NEK }\end{array}$ & $\begin{array}{l}\text { Počet klasifikovaných } \\
\text { útvarů povrchových vod }\end{array}$ \\
\hline $\begin{array}{l}\text { halogeny adsorbovatelné organicky vázané } \\
\text { (AOX) }\end{array}$ & 14,1 & 147 & 499 \\
\hline metabolity alachloru & 12,8 & 134 & 424 \\
\hline bisfenol A & 7,7 & 80 & 339 \\
\hline fenantren & 7,3 & 76 & 451 \\
\hline malathion & 7,2 & 75 & 376 \\
\hline železo & 6,6 & 69 & 650 \\
\hline pyren & 6,4 & 67 & 451 \\
\hline metolachlor a jeho metabolity & 4,7 & 49 & 460 \\
\hline kyselina ethylendiamintetraoctová & 4,2 & 44 & 115 \\
\hline mangan & 3,2 & 33 & 572 \\
\hline uhlovodíky $C_{10}-C_{40}$ & 2,4 & 25 & 297 \\
\hline arsen & 1,3 & 14 & 595 \\
\hline benzo[a]antracen & 1,0 & 10 & 451 \\
\hline fenthion & 1,0 & 10 & 278 \\
\hline MCPA (kyselina 4-chloro-o-tolyloxyoctová) & 1,0 & 10 & 418 \\
\hline selen & 1,0 & 10 & 380 \\
\hline
\end{tabular}

Graficky je hodnocení ekologického stavu/potenciálu útvarů kategorie „řeka" s rozdělením na jednotlivé hodnocené složky uvedeno na obr. 2.

Z výše uvedených výsledků vyplývá, že klíčovými parametry nebo složkami, které jsou určující pro zařazení tvarů kategorie „řeka“ do středního a horšího stavu jsou makrozoobentos a fytobentos a ze všeobecných fyzikálně-chemických složek jsou to celkový fosfor, dusičnanový a amoniakální dusík. Pro specifické znečištujuící látky je podrobnější hodnocení uvedeno v následující tabulce 4, kde je přehled vybraných specifických znečištujících látek, u nichž došlo k překročení normy environmentální kvality (dále jen NEK) u více než 1 \% všech útvarů povrchových vod kategorie „řeka“.

Z výše uvedených výsledků vyplývá, že nejvyšší procento překročení NEK u útvarů kategorie „řeka” bylo zaznamenáno v prípadě specifických znečištujících látek u parametrů - AOX, metabolity alachloru, bisfenol A, fenantren a malathion.

Ekologický potenciál útvarů povrchových vod kategorie „jezero“ je uveden $\vee$ grafickém znázornění pro jednotlivé složky hodnocení na obr. 3.

Z výše uvedeného grafického znázornění vyplývá, že určujícími složkami pro zařazení útvarů povrchových vod kategorie "jezero" do středního a horšího potenciálu byl fytoplankton, všeobecné fyzikálně-chemické složky - celkový fosfor a průhlednost a některé specifické znečištujujicí látky.

Přehled souhrnného hodnocení ekologického stavu/potenciálu útvarů povrchových vod za období 2013-2015 v České republice je v mapové podobě uveden na obr. 4.
Souhrnně lze konstatovat, že ekologický stav/potenciál útvarů povrchových vod kategorie „řeka“ dosahoval středního a horšího stavu/potenciálu u více než 86 \% útvarů a pro kategorii "jezero" byl střední a horší potenciál zaznamenán u více než $76 \%$ útvarů.

\section{Chemický stav útvarů povrchových vod}

$\checkmark$ následující tabulce 5 je uveden přehled výsledků hodnocení chemického stavu útvarů povrchových vod kategorie "řeka“ a "jezero" za období 2013-2015. Dále na obr. 5 je znázorněno graficky procentuální hodnocení chemického stavu útvarů povrchových vod pro obě kategorie.

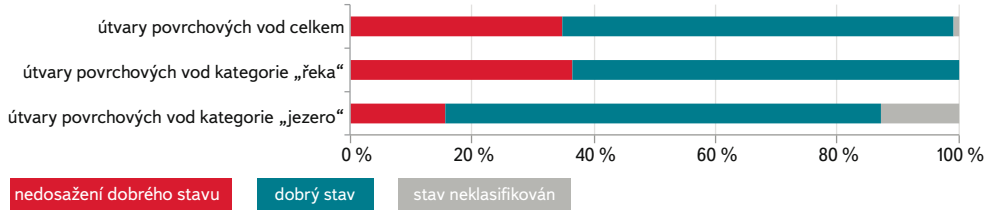

Obr. 5. Chemický stav útvarů povrchových vod kategorie „řka"/,jezero"

Fig. 5. Chemical status of the surface water bodies in categories "river" and "lake" 
Tabulka 5. Chemický stav útvarů povrchových vod kategorie "reka" a "jezero" Table 5. Chemical status of the surface water bodies in categories "river" and "lake"

\begin{tabular}{lll} 
Chemický stav & $\begin{array}{l}\text { Počet útvarů } \\
\text { povrchových } \\
\text { vod }\end{array}$ & $\begin{array}{l}\text { Procento } \\
\text { útvarů } \\
\text { povrchových } \\
\text { vod }\end{array}$ \\
\hline Kategorie „řeka“ & $\mathbf{1 0 4 4}$ & $\mathbf{1 0 0}$ \\
\hline dobrý stav & 664 & 63,6 \\
\hline nedosažení dobrého stavu & 380 & 36,4 \\
\hline stav nehodnocen & 0 & 0 \\
\hline Kategorie „jezero“ & $\mathbf{7 7}$ & $\mathbf{1 0 0}$ \\
\hline dobrý stav & 55 & 71,4 \\
\hline nedosažení dobrého stavu & 12 & 15,6 \\
\hline stav neklasifikován & 10 & 13,0
\end{tabular}

V následující tabulce 6 jsou uvedeny prioritní a prioritní nebezpečné látky, u nichž v hodnoceném období 2013-2015 došlo k překročení NEK u více než 1 \% útvarů kategorie „řeka”.

Z výše uvedené tabulky vyplývá, že nejproblematičtějšími parametry v rámci hodnocení chemického stavu útvarů povrchových vod kategorie „řeka“ byly v hodnoceném období 2013-2015 ukazatele ze skupiny polycyklických aromatických uhlovodíků - fluoranthen, benzo(a)pyren, benzo(ghi)perylen, benzo(b)fluoranthen a benzo(k)fluoranthen.

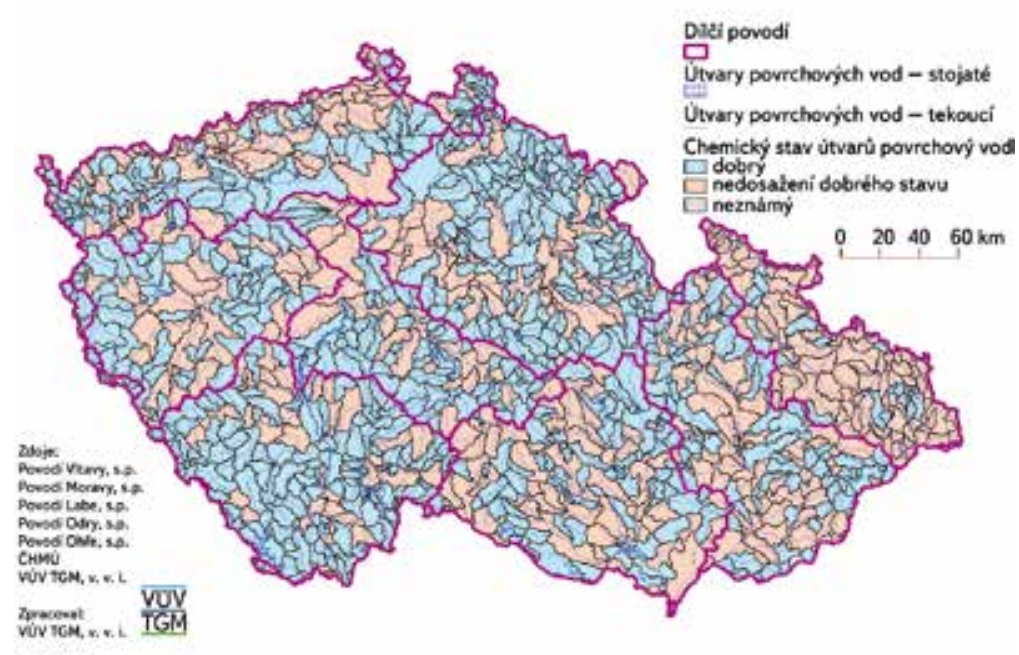

conen zent

Obr. 6. Chemický stav útvarů povrchových vod za období 2013-2015 v České republice Fig. 6. Chemical status of the surface water bodies for the period 2013-2015 in the Czech Republic

Přehled hodnocení chemického stavu útvarů povrchových vod v České republice je mapově znázorněn na obr. 6 .

V hodnoceném období 2013-2015 Ize konstatovat, že 64 \% útvarů povrchových vod kategorie „řeka“ bylo v dobrém chemickém stavu a 36 \% vykazovalo nedosažení dobrého stavu. $\vee$ prípadě útvarů povrchových vod kategorie „jezero" bylo v dobrém chemickém stavu $71 \%$ a naopak $15 \%$ nedosahovalo dobrého chemického stavu. V této souvislosti je však rovněž nutné zmínit, že důležitou úlohu v tomto hodnocení sehrává vlastní monitoring povrchových vod, který v prípadě parametrů pro hodnocení chemického stavu pokrýval celkově

Tabulka 6. Vybrané prioritni a prioritní nebezpečné látky, které prekekračuji NEK u více než $1 \%$ útvarü povrchových vod kategorie „řeka" Table 6. Selected priority and priority dangerous substances exceeding EQS in more than 1\% surface water bodies in category "river"

\begin{tabular}{|c|c|c|c|}
\hline Látka & $\begin{array}{l}\text { Procento útvarů } \\
\text { povrchových vod } \\
\text { s překročením NEK (\%) }\end{array}$ & $\begin{array}{l}\text { Počet útvarů povrchových } \\
\text { vod s překročením NEK }\end{array}$ & $\begin{array}{l}\text { Počet klasifikovaných } \\
\text { útvarů povrchových vod }\end{array}$ \\
\hline fluoranthen & 27,5 & 287 & 450 \\
\hline benzo[a]pyren & 19,3 & 202 & 202 \\
\hline benzo[ghi]perylen & 17,6 & 184 & 451 \\
\hline benzo[b]fluoranthen & 15,2 & 159 & 450 \\
\hline benzo[k]fluoranthen & 7,1 & 74 & 450 \\
\hline nikl a jeho sloučeniny - rozpuštěný & 6,0 & 63 & 607 \\
\hline rtut a její sloučeniny - rozpuštěná & 3,3 & 34 & 458 \\
\hline kadmium a jeho sloučeniny - rozpuštěné & 3,0 & 31 & 595 \\
\hline bromovaný difenylether, PBDE & 2,0 & 21 & 229 \\
\hline di(2-ethylhexyl)ftalát (DEHP) & 1,5 & 16 & 209 \\
\hline olovo a jeho sloučeniny - rozpuštěné & 1,1 & 12 & 608 \\
\hline
\end{tabular}


jen cca $70 \%$ reprezentativních profilů útvarů povrchových vod. Současně byl i rozsah sledovaných prioritních a prioritních nebezpečných látek v rámci České republiky velmi variabilní.

\section{DOPORUČENÍ PRO OPTIMALIZACI PROCESU HODNOCENÍ STAVU POVRCHOVÝCH VOD}

Výzkumný ústav vodohospodářský T. G. Masaryka, v. v. i., na základě zkušeností ze zpracování hodnocení stavu útvarů povrchových vod kategorie „řeka“ a "jezero" za období 2010-2012 a 2013-2015 navrhl ve spolupráci s ČHMú níže uvedená doporučení. Tato doporučení si kladou za cíl zefektivnit realizaci hodnocení stavu povrchových vod na národní úrovni za období 2016-2018 pro 3. plány povodí a umožnit jeho zpracování v optimálním časovém horizontu, který bude minimalizovat možné zpoždění vzhledem k požadavkům časového plánu a programu prací pro jejich prípravu a zpracování.

\section{Seznam reprezentativních profilů pro hodnocení stavu povrchových vod}

Před samotnou realizací hodnocení stavu povrchových vod pro 3. plány povodí je potřeba v dostatečném předstihu mít k dispozici finální seznam reprezentativních profilů pro hodnocení stavu útvarů povrchových vod kategorie "řeka" a "jezero", přičemž lze v obou prípadech jako základ využít seznamy uvedené v Rámcovém programu monitoringu. V prípadě vodních útvarů kategorie „řeka" je nutné i doplnění typologických a abiotických charakteristik, jako jsou geologie, úmoří, rád toku, nadmořská výška reprezentativního profilu, sklonitost, délka toku od pramene, apod. Současně je rovněž nutné k definovaným profilům mít jejich jednoznačnou identifikaci. Za součást identifikace lze považovat nejen ID ale i název profilu, název vodního toku a souřadnice, pokud možno $\checkmark$ souřadnicovém systému S-JTSK. Kvůli jednoznačnému určení výše uvedených typologických a abiotických charakteristik by bylo vhodné rovněž k těmto údajům prìdat ID vodního toku podle Centrální evidence vodních toků jakožto oficiální databáze (alternativně podle Digitální báze vodohospodářských dat) a zejména číslo hydrologického pořadí podle oficiální datové vrstvy ČHMÚ, která je státním podnikům Povodí dostupná. Je nutné dále odstranit určité technické problémy, pokud jde o „jedinečné“ ID profilů, a to zejména vzhledem k tomu, že v současnosti neexistuje jednoznačná identifikace v rámci celé České republiky. Aby se identifikátory nemohly mezi jednotlivými státními podniky Povodí prékrývat, předřazuje VúV TGM před ID i kód státního podniku Povodí (přičemž se předpokládá, že ID profilu je v jejich databázích jedinečné). Zcela nepřípustné by mělo být nadále používání identifikátorů zrušených profilů pro profily nové, obzvláště pokud jsou lokalizovány ve zcela jiném vodním útvaru. Uvedené identifikační údaje by měly být v databázích státních podniků Povodí a IS ARROW vždy shodné. Jako velmi prínosné se jeví dohodnout způsob celostátně jednoznačné a všemi zainteresovanými subjekty používané identifikace profilů.

Je nutné vyřešit i problematiku jednotných ID u profilů ve vodních útvarech kategorie "jezero", kde část parametrů je stanovována z integrálního vzorku z hloubky 3-4 m a část parametrů ze zonálních měření sondou. Pro hodnocení stavu vodních útvarů kategorie "jezero" je vhodné používat jedno ID pro hodnocený profil podobně jako u útvarů povrchových vod kategorie „řeka“.

Rovněž je důležité do IS ARROW k reprezentativním profilům zavést informaci o príslušných vodních útvarech (ID + název), které daný profil hodnotí. Současně před samotným hodnocením by bylo vhodné mít přehled o rozsahu monitorovaných biologických složek $v$ reprezentativních profilech $v$ daném hodnoceném období.

\section{Aktualizace metodických postupů hodnocení stavu povrchových vod}

Před realizací hodnocení stavu povrchových vod pro 3. plány povodí je nutné mít metodicky dořešen prístup k hodnocení stavu v nemonitorovaných útvarech povrchových vod, a to v obou částech hodnocení - chemický stav i ekologický stav, resp. potenciál.

Podle požadavků Evropské komise zřejmě dojde ke změnám v postupu hodnocení ekologického potenciálu silně ovlivněných vodních útvarů (tj. i u "jezer", které nyní probíhá mimo IS ARROW) - je otázka, jestli bude hodnocení součástí modulu biologického hodnocení. Revizí by měla rovněž projít i metodika na hodnocení ichtyofauny pro útvary kategorie „řeka“. Pokud k určitým změnám hodnocení biologických složek dojde, je pak nezbytné zajištění dodatečného naprogramování nových algoritmů do IS ARROW s náležitou odbornou garancí těchto postupů.

Je potřebné rovněž rozpracovat detaily plánovaného zahrnutí hodnocení hydromorfologie tekoucích i stojatých vod do hodnocení stavu.

\section{Kontrola exportu dat z laboratoří státních podniků Povodí do IS ARROW}

Před hodnocením stavu je účelné provést kontrolu kompletnosti dat a verifikaci datového souboru, který půjde do samotného výpočtu. To Ize provádět již v průběhu tř́letí průběžně, ale je nutné mít definitivní a kompletní datový soubor pro hodnocení stavu pro minimalizaci vzniku nadbytečných verzí výstupů hodnocení stavu. $V$ této souvislosti navrhujeme zavést pravidelnou zpětnou vazbu mezi laboratořemi státních podniků Povodí a ČHMú, jako správce databáze, která by ověrila požadovanou kompletnost exportovaných souborů. Kontrola by měla probíhat na úrovni zaslaných dat ze státních podniků Povodí na ČHMÚ po jejich vložení do IS ARROW. Doporučujeme, aby státní podniky Povodí měly zpětnou informaci s přehledem vložených vzorků a základní statistiku za každou dávku dat, kterou odešlou. Tyto vzorky by měly zkontrolovat a odsouhlasit, že jsou kompletní. S ohledem na výše uvedené by bylo dále vhodné zajistit, aby následný export dat z IS ARROW ke zpracovateli hodnocení stavu povrchových vod byl součástí samotného programu, což se týká především podkladových dat pro hodnocení prioritních a specifických znečištujících látek, aby se minimalizovalo riziko neúplného exportu. V této souvislosti se nám zdá prínosné označit již prímo v IS ARROW relevantní látky pro hodnocení stavu.

Jinak platí, že veškerá data by i nadále měla jít cestou přes IS ARROW, aby se zamezilo poskytování dat v různých formátech a struktuře. Pokud by z nějakého důvodu nebylo možné zajistit kompletní data v IS ARROW, bylo by alternativou posílat data v jednotném povinném formátu XML a struktuře pro zasílání dat do IS ARROW prímo zpracovateli hodnocení.

Rovněž bude nutné zahrnout údaje z odběrového protokolu biologických složek do IS ARROW, zejména z důvodů jejich potřeby při výpočtu jednotlivých metrik pro vyhodnocení stavu.

\section{Kontrola správnosti výpočetních algoritmů pro hodnocení biologických složek v IS ARROW}

Je potřeba definovat přesné odpovědnosti jednotlivých institucí s ohledem na zajištění aktuálních a správných postupů a algoritmů použitých pro výpočet jednotlivých metrik pro všechny biologické složky. Vzhledem k dosavadním zkušenostem je nutné $v$ pravidelných intervalech kontrolovat aktuálnost a správnost výpočetních postupů a jejich použitelnost na modelových testovacích vzorcích dat z monitoringu. Tím je myšleno mít kontinuálně zajištěnu 


\section{Literatura}

[1] Směrnice Evropského parlamentu a Rady 2000/60/ES ze dne 23. ríjna 2000, kterou se stanoví rámec pro činnost Společenství v oblasti vodní politiky.

[2] Zákon č. 254/2001 Sb., o vodách a o změně některých zákonů (vodní zákon) ve znění pozdějších predpisů.

[3] Vyhláška č. 98/2011 Sb., o způsobu hodnocení stavu útvarů povrchových vod, způsobu hodnocen ekologického potenciálu silně ovlivněných a umělých útvarů povrchových vod a náležitostech programů zjištování a hodnocení stavu povrchových vod ve znění pozdějších předpisů.

[4] Směrnice Evropského parlamentu a Rady 2008/105/ES ze dne 16. prosince 2008 o normách environmentální kvality v oblasti vodní politiky, změně a následném zrušení směrnic Rady 82/176/ EHS, 83/513/EHS, 84/156/EHS, 84/491/EHS a 86/280/EHS a o změně směrnice Evropského parlamentu a Rady $2000 / 60 /$ ES

[5] Směrnice Evropského parlamentu a Rady 2013/39/EU ze dne 12. srpna 2013, kterou se měn směrnice 2000/60/ES a 2008/105/ES, pokud jde o prioritní látky v oblasti vodní politiky.

[6] Směrnice Komise 2009/90/ES ze dne 31. července 2009, kterou se podle směrnice Evropského parlamentu a Rady 2000/60//ES stanoví technické specifikace chemické analýzy a monitorován stavu vod.

[7] Vyhláška č. 24/2011 Sb., o plánech povodí a plánech pro zvládání povodňových rizik ve zněn pozdějších předpisů.

[8] VYSKOČ, P., RICHTER, P., MIČANÍK, T. a FILIPPI, R. Vyhodnoceníjakosti povrchovévody z hlediska výskytu prioritnich látek a požadavků směrnice 2008/105/ES. VÚV TGM, v. v. i., MŽP, 2011

[9] ROSENDORF, P. a kol. Metodika hodnocenívšeobecných fyzikálně-chemických složek ekologického stavu útvarů povrchových vod tekoucích. Vúv TGM, v. v. i., 2011.

[10] DURČÁK, M. a kol. Metodika hodnocení ekologického stavu/potenciálu útvarů povrchových vodspecifické znečištujícílátky. Vúv TGM, v. v. i., 2013.

[11] MARVAN, P. a kol. Metodika hodnocení ekologického stavu útvarů povrchových vod tekoucích (kategorie reka) pomocíbiologické složky fytobentos. VÚV TGM, v. v. i., 2011

[12] OPATŘILOVÁ, L. a kol. Metodika hodnocení ekologického stavu útvarů povrchových vod tekoucích pomocíbiologickésložky fytoplankton. VÚV TGM, v. v. i., 2011

[13] KOČí, M. a kol. Metodika hodnoceni ekologického stavu útvarü povrchových vod tekoucích pomoc biologickésložky makrofyta. Vúv TGM, v. v. i., 2011.

[14] HORKÝ, P. a kol. Metodika hodnocení ekologického stavu útvarů povrchových vod tekoucích (kategorie reka) pomocíbiologickésložky ryby. VúV TGM, v. v. i., 2011.

[15] OPATŘILOVÁ, L. a kol. Metodika hodnoceni ekologického stavu útvarů povrchových vod tekoucích (kategorie reka) pomocí biologickésložky makrozoobentos. VÚV TGM, v. v. i., 2011.

[16] NËMEJCOVÁ, D. a kol. Metodika hodnoceníbiologické složky bentičtí bezobratli (makrozoobentos) pro velké nebroditelné reky. VúV TGM, v. v. i., 2013.

[17] OPATR̈ILOVÁ, L. a kol. Metoda pro hodnocení ekologického potenciálu silně ovlivněných a umělých vodních útvarü - kategorie reka. VúV TGM, v. v. i., 2013

[18] BOROVEC, J. a kol. Metodika pro hodnoceni ekologického potenciálu silně ovlivněných a umělých vodních útvarů - kategorie jezero. Biologické centrum AV ČR, v. v. i., 2014

[19] DURČÁK, M. a kol. Metodika hodnoceníchemického stavu útvarů povrchových vod. VúV TGM, v. v. i., 2013.

[20] DURČÁK, M. a kol. Metodika hodnocení chemického a ekologického stavu útvarů povrchových vod kategorie reka pro druhý cyklus plánů povodív ČR. VúV TGM, v. v. i., 2014.

\section{Autoři}

Ing. Petr Tušil, Ph.D., MBA

凶petr.tusil@vuv.cz

Ing. Pavel Richter, Ph.D. ${ }^{2}$

凶pavel.richter@vuv.cz

Ing. Petr Vyskoč ${ }^{2}$

凶petr.vyskoc@vuv.cz

RNDr. Renata Filippi

凶 renata.filippi@vuv.cz

Ing. Martin Durčák

凶martin.durcak@vuv.cz

'Výzkumný ústav vodohospodářský T. G. Masaryka, v. v. i., pobočka Ostrava ${ }^{2}$ Výzkumný ústav vodohospodářský T. G. Masaryka, v. v. i., Praha

Příspěvek prošel lektorským řízením.

\section{THE ASSESSMENT OF THE STATUS OF SURFACE WATER BODIES IN THE CZECH REPUBLIC FOR THE PERIOD 2013-2015}

\section{TUSIL, P.'; RICHTER, P. '; VYSKOC, P.; FILIPPI, R. ${ }^{2}$; DURCAK, M. ${ }^{1}$}

${ }^{1}$ TGM Water Research Institute, p. r. i., Ostrava Branch ${ }^{2}$ TGM Water Research Institute, p. r. i., Prague

Keywords: assessment of the surface water status - surface water body representative monitoring site - ecological status - ecological potential biological elements - chemical status - priority substances

This article aims to present to the general public the results of the assessment of the ecological status/potential and chemical status of surface water bodies categories "river" and "lake" for the period 2013 to 2015 in the Czech Republic. The assessment was carried out in 2017 by the Water Research Institute of T. G. Masaryk, p. r. i. There are also mentioned the procedures and methods used for water status assessment. At the end of the article, specific recommendations are made to ensure that the assessment of surface water status in 2019 will be optimized to the maximum possible extent and that this assessment of surface water status will be one of the essential bases for updating all levels of river basin management plans in 2021. The objective of this article is not a more detailed analysis of the contexts, causes and factors influencing the results of the present assessment of the status of surface water bodies as well as comparison with the results of the assessment of the status of surface water bodies in the first and second planning cycles. 